\title{
Protests against nuclear power stations growing in Japan
}

\section{Tokyo}

ACTIVISTS against nuclear power armed with radiation-monitoring equipment on Wednesday last week (11 May) chased a convoy of nuclear fuel trucks halfway across Japan. The action was part of a blossoming anti-nuclear power movement that is worrying government and industry.

Until the Chernobyl disaster in 1986, there had been little public protest against nuclear power in Japan. Just months after the accident, the Ministry of International Trade and Industry (MITI) announced plans to build 120 nuclear power plants by 2030 to supply 60 per cent of Japan's electricity (see Nature 322, 399; 1986).

But several recent events have changed the mood. First came reports that some imported foodstuffs, such as nuts, macaroni and tea, contain Chernobyl-derived radioactivity. Although the amounts were in most cases only a few tens of becquerels per kilogram, far below safety limits set in the West and Japan, several food cooperatives banned sale of the products.

Then, in February, thousands turned out to protest against a power modulation experiment at the Ikata nuclear plant in the island of Shikoku. And at the end of last month, nearly 10,000 people staged rallies, lectures and protest marches in Tokyo to mark the second anniversary of Chernobyl.

New nuclear plants open in Japan almost every year, and the percentage of electricity produced by nuclear power is rapidly rising, at present accounting for about a third of Japan's output. As a result, it will soon be necessary to modulate nuclear power plant output to meet hourly fluctuations of demand. At present, nuclear plants run at full capacity and fluctuations are accommodated by conventional power plants. But protesters say the manual operations required to modulate power will increase the risk of a nuclear accident.

Another concern is that huge amounts of nuclear fuel, spent fuel and waste are being shipped around Japan in trucks, often unannounced and through densely populated areas, including Tokyo leading to last week's scheme to trail a convoy of trucks carrying fuel rods for 900 $\mathrm{km}$ from the Japan Nuclear Fuel factory in Yokosuka, south of Tokyo, to a power plant at Matsue city on the coast of the Japan Sea.

But government officials and leaders of the nuclear power industry have risen to the protesters' challenge. At the opening of the Japan Atomic Industrial Forum's annual conference last month, Soichiro Ito, head of the Science and Technology Agency, and Jiro Enjoji, chairman of the forum, called on the nuclear industry to mount public information campaigns to deter further opposition.

Tokyo Electric Power Co., one of Japan's most profitable companies with an annual income of about 500,000 million yen $(\$ 4,000$ million $)$, has announced a 20 per cent increase in its public relations budget. And in an unprecedented move last week (12 May), Hajime Tamura, head

\section{IMAGE UNAVAILABLE FOR COPYRIGHT REASONS}

"What is going to happen mummy? (nani ga okoru no okaasan) asks this poster, designed by an anti-nuclear group in Akita Prefecture headed by Giro Hirayama. (Kyodo Photo.)

of MITI, summoned the presidents of Japan's nine electric power companies to urge them to do more in the field.

Tamura is concerned that the protest movement has spread from the vicinity of power plants to Japan's major cities. He says the protests are not based on expert knowledge but on simplistic slogans such as "nuclear power is dangerous" and "there is a surplus of electricity".

But the campaigns are becoming increasingly sophisticated. Activists have designed an appealing poster of a mother dressing a child in a protective radiation suit while the child asks "what is going to happen mummy?". The protesters who followed the convoy of trucks from Yokosuka to Matsue carried radiationmonitoring equipment and claim that, when the convoy pulled into a service station on Wednesday night, nearby radiation levels were more than 100 times that of natural background.

With the government planning to begin the airlifting of reprocessed plutonium from Europe to Japan in the 1990s, it seems certain that opposition to nuclear power will continue to grow

David Swinbanks

\section{US/Soviet accord}

\section{Washington}

A YEAR-LONG Soviet-American conference on the global causes and symptoms of the greenhouse effect, to be conducted by electronic mail, was inaugurated last week with an exchange of computer messages between Moscow and Washington. Roald Sagdeev, director of the Soviet Institute for Space Research, and ex-astronaut Russell Schweickart were in Washington to congratulate, over a telephone line, Walter Roberts, co-chairman of the US side, who had gone to Moscow to receive their greetings.

Fourteen American and ten Russian participants will be able to exchange their ideas on greenhouse warming through a specially created electronic mailbox on a commercial network. The European Space Agency provided the electronic link for the Soviet side, and has three participants. On the question of possible censorship Sagdeev said both sides would send whatever messages they thought fit until their computer screens were interrupted with a "warning from Big Brother".

David Lindley

\section{Global databases}

\section{London}

THE International Geographical Union last week agreed to take the first steps towards establishing a coordinated international strategy on the gathering, handling and dissemination of information on global processes. More than $\mathbf{5 0}$ experts from a dozen countries, including the United States, the Soviet Union and China, met in Hampshire, England, to discuss how the international scientific community can best use the huge quantities of information being generated through techniques such as remote sensing by satellite. Computerized databases have already been established by several international agencies, but more thought is needed about how best to go about setting up and exploiting databases if the international community is to derive the maximum benefit from them. The union concedes that the problems associated with setting up internationally accessible global data bases are immense, but have to be tackled.

Following the five-day meeting last week it was agreed to establish a working group to consider the legal issues of control, ownership, liability and copyright regarding the construction, maintenance and use of global databases. Efforts will also be made to develop standards for interchange of data bases between scientists and international agencies in the areas of data quality and formats. The union will start to identify what moves will be needed to improve accessibility to global data and its usefulness to people working in programmes related to the global environment.

Simon Hadlington 